\title{
UJI AKTIVITAS ANTIBAKTERI KRIM ASAM LAURAT TERHADAP Staphylococcus aureus ATCC 25923 DAN Pseudomonas aeruginosa ATCC 27853
}

\section{(ANTIBACTERIAL ACTIVITY TEST OF LAURIC ACID CREAM AGAINST Staphylococcus aureus ATCC 25923 AND Pseudomonas aeruginosa ATCC 27853)}

\author{
Evi Sulastri $^{1^{*}}$, Mappiratu ${ }^{2}$, Annisa Kartika Sari ${ }^{1}$ \\ ${ }^{1}$ Jurusan Farmasi, Fakultas MIPA, Universitas Tadulako, Palu, Indonesia \\ ${ }^{2}$ Jurusan Kimia, Fakultas MIPA, Universitas Tadulako, Palu, Indonesia
}

Received 25 Juli 2016, Accepted 30 Agustus 2016

\begin{abstract}
A B S T R A K
Asam laurat merupakan asam lemak jenuh yang terdapat dalam lemak/minyak nabati terutama dalam minyak kelapa. Asam laurat memiliki manfaat sebagai antivirus dan antibakteri. Penelitian ini bertujuan untuk mengetahui pengaruh variasi konsentrasi asam laurat dalam sediaan krim terhadap stabilitas mutu fisik krim dan aktivitas antibakterinya terhadap Staphylococcus aureus dan Pseudomonas aeruginosa. Pada penelitian ini dilakukan variasi konsentrasi asam laurat dalam sediaan krim yakni 10\%, 20\%, dan 30\% kemudian dilakukan pengujian aktivitas antibakteri menggunakan metode difusi sumur. Hasil evaluasi sediaan krim asam laurat Formula 1, Formula 2, dan Formula 3 menunjukkan bahwa pada pemeriksaan organoleptis dan homogenitas tidak terjadi perubahan terhadap ketiga formula selama waktu simpan, tetapi pada pemeriksaan $\mathrm{pH}$, viskositas, dan daya sebar terjadi perubahan terhadap ketiga formula selama waktu simpan (28 hari). Hasil pengujian antibakteri menunjukkan diameter daya hambat tertinggi terdapat pada penggunaan konsentrasi asam laurat $30 \%$ untuk S.aureus yakni sebesar 21,589 mm $\pm 0,18$ dan P.aeruginosa yakni sebesar 14,25 mm $\pm 0,37$. Berdasarkan analisis statistik krim yang dihasilkan dari tiga konsentrasi asam laurat belum dapat dikatakan stabil sebab terdapat perbedaan signifikan pada $\mathrm{pH}$, viskositas, dan daya sebar selama waktu penyimpanan 28 hari.
\end{abstract}

Kata Kunci : asam laurat, krim antibakteri, Staphylococcus aureus, Pseudomonasaeruginosa.

\section{A B S T R A C T}

Lauric acid is a saturated fatty acid found in fatty/vegetable oils, especially in palm oil. Lauric acid was reported to posses antiviral and antibacterial property. This study aims to determine the effect of the concentration variance of lauric acid in cream on the stability of the cream physical quality and antibacterial activity against Staphylococcus aureus and Pseudomonas aeruginosa. In this research, lauric acid concentration in cream was varied in $10 \%, 20 \%$, and $30 \%$ and then tested for antibacterial activity using hole plate technique. The results of the evaluation of lauric acid cream preparation of Formula 1, Formula 2 and Formula 3 showed that the organoleptic and homogeneity tests of all formula was no difference during storage time, but the result of $\mathrm{pH}$, viscosity, and dispersive power of all formula has difference during storage time (28 days). The antibacterial test results showed that the highest inhibition diameter was found in the use of lauric acid concentration of $30 \%$ for S.aureus $(21.589 \mathrm{~mm} \pm 0.18)$ and P.aeruginosa $(14.25 \pm 0.37 \mathrm{~mm})$. Based on statistical analysis of the cream produced from the three concentrations of lauric acid, they were not stable because there are significant differences in $\mathrm{pH}$, viscosity, and dispersive power during storage time (28 days).

Keywords: lauric acid, antibacterialcream, Staphylococcus aureus, Pseudomonas aeruginosa.

*Coresponding Author : Evi Sulastri evisulas3@gmail.com (ph: +62-852-9913-2298) 


\section{PENDAHULUAN}

Asam laurat adalah suatu asam lemak jenuh yang terdapat dalam lemak/minyak nabati terutama dalam minyak kelapa. Disamping itu asam laurat berfungsi sebagai antivirus dan antibakteri. Asam laurat dalam tubuh akan diubah menjadi senyawa Monolaurin yang mempunyai kemampuan antiprotozoa, antibakteri serta antivirus dan kini sedang dikembangkan sebagai antivirus HIV (Human Immunodeficiency Virus) (Tuminah, 2010). Preparasi dari asam laurat dapat melindungi kulit dari infeksi bakteri (Kabara, 1984).

Berdasarkan penelitian sebelumnya asam laurat pada konsentrasi $1,6 \mathrm{mg} / \mathrm{ml}, 3,2 \mathrm{mg} / \mathrm{ml}$, dan $6,4 \mathrm{mg} / \mathrm{ml}$ dapat menghambat pertumbuhan bakteri Staphylococcus aureus ATCC 25923 berturut-turut sebesar 6,0 $\pm 0,71$ $\mathrm{mm}, 10,0 \pm 0,71 \mathrm{~mm}$, dan $11,0 \pm 1,41 \mathrm{~mm}$ (Tangwatcharin and Khopaibool, 2012).

Infeksi oleh Staphylococcus aureus ditandai dengan kerusakan jaringan yang disertai abses bernanah.Beberapa penyakit infeksi yang disebabkan oleh Staphylococcus aureus adalah bisul, jerawat, impetigo, dan sebagainya (Ryan, et al., 1994; Warsa, 1994).Selain Staphylococcus aureus, bakteri yang dapat menginfeksi kulit yakni Pseudomonas aeruginosa. Bakteri ini sering terdapat pada kulit manusia, serta merupakan patogen utama dari kelompoknya. Bakteri ini kadang-kadang mengkoloni pada manusia dan menimbulkan infeksi apabila fungsi pertahanan inang abnormal. Oleh karena itu, Pseudomonas aeruginosa disebut patogen oportunistik, yaitu memanfaatkan kerusakan pada mekanisme pertahanan inang untuk memulai suatu infeksi (Mayasari, 2005; Jawetz et al, 2004).

Krim adalah sediaan padat yang mengandung satu atau lebih bahan obat terlarut dalam bahan dasar yang sesuai. Istilah ini secara tradisional telah digunakan untuk sediaan setengah padat yang mempunyai konsistensi relatif cair yang diformulasikan sebagai emulsi air dalam minyak atau minyak dalam air (Anonim, 1995).

Krim dipilih karena sediaan ini mempunyai keuntungan diantaranya mudah dioleskan pada kulit, mudah dicuci setelah dioleskan, mudah berpenetrasi pada kulit, dan terdistribusi merata. Krim yang digunakan sebagai obat umumnya digunakan untuk mengatasi penyakit kulit seperti jamur, infeksi ataupun sebagai anti radang yang disebabkan oleh berbagai jenis penyakit (Anwar, 2012).

Berdasarkan penjelasan di atas maka perlu dilakukan penelitian untuk mengetahui aktivitas antibakteri dari asam laurat dengan 3 variasi konsentrasi berbeda $(10 \%, 20 \%$, dan $30 \%$ ) yang dibuat dalam suatu sediaan farmasi yang dapat memudahkan dalam penggunaannya yaitu krim.

\section{BAHAN DAN METODE BAHAN}

Bahan-bahan yang digunakan dalam penelitian ini adalah Asam laurat, Aquadest, Parafin liquidum, Asam stearat, Setil alkohol, Poloxamer 407, Span 60, Butil Hidroksi Toluen (BHT), Propilen glikol, Propil paraben, Metil paraben, aluminium foil, bakteri Staphylococcus aureus ATCC 25923, bakteri Pseudomonas aeruginosa ATCC 27853, media Nutrient Agar $\left(\right.$ MERCK $\left.^{\circledR}\right), \quad$ krim Gentamisin 0,1\%, Tween 80, etanol 96\%, kapas steril, kertas label.

\section{METODE}

\section{Formulasi krim asam laurat}

Formulasi krim asam laurat dapat dilihat pada tabel dibawah ini :

Tabel 1. Formula Krim

\begin{tabular}{lllccccc} 
No & Nama Bahan & Kegunaan & \multicolumn{5}{c}{ Konsentrasi (\%) } \\
\cline { 4 - 7 } & & & F0 & F1 & F2 & F3 & F4 \\
\hline 1. & Asam laurat & Bahan aktif & 0 & 10 & 20 & 30 & \\
2. & Paraffin cair & Emolien & 3 & 3 & 3 & 3 & \\
3. & Poloxamer 407 + Span 60 & Emulgator & 5 & 5 & 5 & 5 & \\
4. & Asam stearat & Peningkat & 10 & 10 & 10 & 10 & Kontrol \\
& & konsistensi & & & & & \\
5. & Setil alcohol & Peningkat & 10 & 10 & 10 & 10 & Positif \\
\hline
\end{tabular}




\begin{tabular}{lllcccc}
\hline & & konsistensi & & & & \\
6. & Propilenglikol & Humektan & 15 & 15 & 15 & 15 \\
7. & Butil Hidroksi Toluen (BHT) & Antioksidan & 0,1 & 0,1 & 0,1 & 0,1 \\
8. & Propil Paraben & Pengawet & 0,01 & 0,01 & 0,01 & 0,01 \\
9. & Metil Paraben & Pengawet & 0,02 & 0,02 & 0,02 & 0,02 \\
10. & Aquadest ad & Pelarut & 100 & 100 & 100 & 100 \\
\hline
\end{tabular}

\section{Cara Pembuatan Krim Asam Laurat}

Bahan-bahan yang terdapat dalam formula dipisahkan dalam dua kelompok, yaitu fase minyak (asam laurat, paraffin cair, asam stearat, setil alkohol, span 60 , butil hidroksi toluene, propil paraben) dan fase air (poloxamer 407, propilenglikol, metil paraben, aquadest). Untuk fase minyak, dipanaskan pada suhu $50^{\circ} \mathrm{C}$ dan fase air dipanaskan pada suhu $70^{\circ} \mathrm{C}$ di penangas air. Fase minyak dan fase air dicampurkan sekaligus lalu dihomogenkan dengan cara digerus menggunakan mortir dan stamper sampai terbentuk massa krim yang homogen. Kemudian disimpan dalam wadah krim yang telah disiapkan.

\section{Pengujian Stabilitas Fisik Krim}

1. Pengamatan Organoleptik sediaan

Evaluasi organoleptis secara visual mulai dari bentuk, krim, aroma, dan warna krim.

2. Pengujian homogenitas sediaan

Diambil 0,1 g krim asam laurat pada bagian atas, tengah, dan bawah kemudian dioleskan pada sekeping kaca transparan. Diamati jika terjadi pemisahan fase.

3. Pengukuran $\mathrm{pH}$ sediaan Krim

Ditimbang sebanyak $1 \mathrm{~g}$ krim asam laurat dan diencerkan dengan $10 \mathrm{ml}$ aquadest. Alat $\mathrm{pH}$ meter dikalibrasi, kemudian masukkan elektrodenya ke dalam sediaan krim yang telah dilarutkan dengan aquadest.

4. Pengukuran viskositas

Pengujian viskositas dilakukan terhadap masing-masing sediaan krim. Viskositas diukur dengan alat viscometer Brookfield dengan menggunakan spindle nomor 6.

5. Pengukuran Daya Sebar

Ditimbang krim asam laurat sebanyak 0,5 g, kemudian diletakkan dengan hati-hati di atas lempeng kaca berukuran $20 \times 20 \mathrm{~cm}$. Selanjutnya ditutupi dengan lempeng kaca yang lain dan digunakan pemberat diatasnya hingga bobot mencapai $125 \mathrm{~g}$ dan diukur diameternya setelah 1 menit.

\section{Penyiapan Bakteri Staphylococcus aureus dan Pseudomonas aeruginosa}

\section{Pembuatan Medium}

Medium Nutrien Agar (NA) ditimbang sebanyak $20 \mathrm{~g}$ dan dilarutkan dalam 1 liter aquadest kemudian dipanaskan diatas water bath atau penangas air sampai jernih dan disterilkan dalam autoklaf selama 15 menit pada suhu $121^{\circ} \mathrm{C}$ dan tekanan 2 atm.

2. Pembuatan suspensi bakteri

Kultur bakteri uji (Staphylococcus aureus dan Pseudomonas aeruginosa)dalam agar miring Nutrient Agar (NA) diambil satu ose dan diinokulasikan dalam $5 \mathrm{ml} \mathrm{NaCl}$ fisiologis secara aseptik, homogenkan, dengan vortex kemudian diinkubasi pada suhu $37^{\circ} \mathrm{C}$ selama 2 jam. Hasil kekeruhan yang digunakan setara dengan standar Mc Farland 1 dengan konsentrasi bakteri $3 \times 10^{8} \mathrm{CFU} / \mathrm{ml}$.

3. Pembuatan larutan uji

Pembuatan larutan uji krim asam laurat dilakukan dengan cara sebagai berikut :

a) Basis krim (kontrol negatif) ( $\left.\mathrm{F}_{0}\right)$ ditimbang sebanyak 1 gram kemudian dilarutkan dengan etanol $96 \%$ hingga $5 \mathrm{ml}$.

b) Krim asam laurat $10 \%\left(\mathrm{~F}_{1}\right)$ ditimbang sebanyak 1 gram kemudian dilarutkan dengan etanol $96 \%$ hingga $5 \mathrm{ml}$.

c) Krim asam laurat $20 \%\left(\mathrm{~F}_{2}\right)$ ditimbang sebanyak 1 gram kemudian dilarutkan dengan etanol $96 \%$ hingga $5 \mathrm{ml}$.

d) Krim asam laurat $30 \%$ (F3) ditimbang sebanyak 1 gram kemudian dilarutkan dengan etanol 96\% hingga $5 \mathrm{ml}$.

e) Krim Gentamisin (kontrol positif) ( $\mathrm{F} 4)$ ditimbang sebanyak 1 gram kemudian dilarutkan dengan etanol 96\% hingga $5 \mathrm{ml}$.

4. Pengujian Aktivitas Antibakteri

Bakteri uji yang digunakan adalah

bakteri Staphylococcus aureus dan Pseudomonas aeruginosa yang diperoleh dari kultur murni UPT. Laboratorium Kesehatan Provinsi Sulawesi Tengah. Pengujian aktivitas antibakteri krim asam laurat terhadap Staphylococcus aureus dan Pseudomonas 
aeruginosa dilakukan dengan menggunakan metode difusi sumur sebagai berikut : Suspensi bakteri uji Staphylococcus aureus dan Pseudomonas aeruginosa dalam suspensi diambil menggunakan mikropipet sebanyak $100 \mu \mathrm{l}$ dimasukkan ke dalam cawan petri, kemudian media NA (Nutrient agar) dituangkan ke dalam cawan-cawan petri steril secara aseptik masing-masing $25 \mathrm{ml}$, homogenkan dengan cara menggoyang membentuk angka 8. Cawan-cawan petri tersebut dibekukan dalam lemari pendingin, kemudian dibuat lubang (sumur) dengan diameter sekitar $6 \mathrm{~mm}$ menggunakan alat pelubang steril. Larutan uji krim asam laurat dengan konsentrasi $0 \%$ (kontrol negatif), 10\%, $20 \%$, dan $30 \%$, sebelumnya di tambahkan $1 \mathrm{ml}$ tween 80 untuk menonaktifkan zat pengawet yang terdapat dalam sediaan, serta larutan uji kontrol positif (Krim Gentamisin) yang akan Tabel 2. Hasil Uji Organoleptik dan Homogenitas diuji diambil sebanyak $50 \mu$ l, kemudian dimasukkan ke dalam sumur dan dibiarkan berdifusi, selanjutnya diinkubasikan pada suhu $37^{\circ} \mathrm{C}$ selama 24 jam. Areal bening yang menunjukkan daerah hambat disekitar sumur diukur mulai dari tepi sumur menggunakan alat ukur jangka sorong.

\section{HASIL DAN PEMBAHASAN}

\section{Hasil Stabilitas Sediaan Krim Asam Laurat}

Pengamatan stabilitas sediaan krim Asam Laurat Formula 1, Formula 2, dan Formula 3 dilakukan selama 28 hari dengan selang waktu pemeriksaan 7 hari yang meliputi pemeriksaan organoleptik, homogenitas, $\mathrm{pH}$, daya sebar, dan viskositas dapat dilihat pada tabel dibawah ini :

\begin{tabular}{|c|c|c|c|c|c|c|}
\hline \multirow{2}{*}{ Pemeriksaan } & \multirow{2}{*}{ Sediaan } & \multicolumn{5}{|c|}{ Lama Penyimpanan (Hari) } \\
\hline & & $\mathbf{0}$ & 7 & 14 & 21 & 28 \\
\hline \multirow[t]{5}{*}{ Organoleptik } & F1 & $\begin{array}{l}\text { Warna putih, } \\
\text { aroma khas } \\
\text { asam laurat, } \\
\text { membentuk } \\
\text { konsistensi } \\
\text { semisolid }\end{array}$ & $\begin{array}{l}\text { Warna putih, } \\
\text { aroma khas } \\
\text { asam laurat, } \\
\text { membentuk } \\
\text { konsistensi } \\
\text { semisolid }\end{array}$ & $\begin{array}{l}\text { Warna putih, } \\
\text { aroma khas } \\
\text { asam laurat, } \\
\text { membentuk } \\
\text { konsistensi } \\
\text { semisolid }\end{array}$ & $\begin{array}{l}\text { Warna putih, } \\
\text { aroma khas } \\
\text { asam laurat, } \\
\text { membentuk } \\
\text { konsistensi } \\
\text { semisolid }\end{array}$ & $\begin{array}{l}\text { Warna putih, } \\
\text { aroma khas } \\
\text { asam laurat, } \\
\text { membentuk } \\
\text { konsistensi } \\
\text { semisolid }\end{array}$ \\
\hline & F2 & $\begin{array}{l}\text { Warna putih, } \\
\text { aroma khas } \\
\text { asam laurat, } \\
\text { membentuk } \\
\text { konsistensi } \\
\text { semisolid }\end{array}$ & $\begin{array}{l}\text { Warna putih, } \\
\text { aroma khas } \\
\text { asam laurat, } \\
\text { membentuk } \\
\text { konsistensi } \\
\text { semisolid }\end{array}$ & $\begin{array}{l}\text { Warna putih, } \\
\text { aroma khas } \\
\text { asam laurat, } \\
\text { membentuk } \\
\text { konsistensi } \\
\text { semisolid }\end{array}$ & $\begin{array}{l}\text { Warna putih, } \\
\text { aroma khas } \\
\text { asam laurat, } \\
\text { membentuk } \\
\text { konsistensi } \\
\text { semisolid }\end{array}$ & $\begin{array}{l}\text { Warna putih, } \\
\text { aroma khas } \\
\text { asam laurat, } \\
\text { membentuk } \\
\text { konsistensi } \\
\text { semisolid }\end{array}$ \\
\hline & F3 & Warna putih & Warna putih & Warna putih & Warna putih & Warna putih \\
\hline & & $\begin{array}{l}\text { kekuningan, } \\
\text { aroma khas } \\
\text { asam laurat, } \\
\text { membentuk }\end{array}$ & $\begin{array}{l}\text { kekuningan, } \\
\text { aroma khas } \\
\text { asam laurat, } \\
\text { membentuk }\end{array}$ & $\begin{array}{l}\text { kekuningan, } \\
\text { aroma khas } \\
\text { asam laurat, } \\
\text { membentuk }\end{array}$ & $\begin{array}{l}\text { kekuningan, } \\
\text { aroma khas } \\
\text { asam laurat, } \\
\text { membentuk }\end{array}$ & $\begin{array}{l}\text { kekuningan, } \\
\text { aroma khas } \\
\text { asam laurat, } \\
\text { membentuk }\end{array}$ \\
\hline & & $\begin{array}{l}\text { konsistensi } \\
\text { semisolid }\end{array}$ & $\begin{array}{l}\text { konsistensi } \\
\text { semisolid }\end{array}$ & $\begin{array}{l}\text { konsistensi } \\
\text { semisolid }\end{array}$ & $\begin{array}{l}\text { konsistensi } \\
\text { semisolid }\end{array}$ & $\begin{array}{l}\text { konsistensi } \\
\text { semisolid }\end{array}$ \\
\hline \multirow[t]{3}{*}{ Homogenitas } & $\mathrm{F} 1$ & Homogen & Homogen & Homogen & Homogen & Homogen \\
\hline & $\mathrm{F} 2$ & Homogen & Homogen & Homogen & Homogen & Homogen \\
\hline & F3 & Homogen & Homogen & Homogen & Homogen & Homogen \\
\hline
\end{tabular}

Tabel 3. Hasil Uji pH, Viskositas, dan Daya Sebar

\begin{tabular}{ccccccc}
\hline \multirow{2}{*}{ Pemeriksaan } & \multirow{2}{*}{ Sediaan } & \multicolumn{5}{c}{ Lama Penyimpanan (Hari) } \\
\cline { 3 - 7 } & & \multicolumn{1}{c}{$\mathbf{0}$} & $\mathbf{7}$ & $\mathbf{1 4}$ & $\mathbf{2 1}$ & $\mathbf{2 8}$ \\
\hline $\mathrm{pH}$ & F1 & $5,66 \pm 0,012$ & $5,62 \pm 0,016$ & $5,45 \pm 0,012$ & $5,37 \pm 0,014$ & $5,29 \pm 0,024$ \\
& F2 & $5,55 \pm 0,016$ & $5,35 \pm 0,012$ & $5,29 \pm 0,024$ & $5,26 \pm 0,018$ & $5,20 \pm 0,004$ \\
& F3 & $5,35 \pm 0,012$ & $5,22 \pm 0,009$ & $5,20 \pm 0,020$ & $5,15 \pm 0,016$ & $5,11 \pm 0,020$ \\
Viskositas (cPs) & F1 & $18346 \pm 37,712$ & $18266 \pm 73,635$ & $18133 \pm 124,7$ & $17620 \pm 32,659$ & $16560 \pm 74,833$
\end{tabular}




\begin{tabular}{cllllll} 
& F2 & $5786 \pm 18,856$ & $5593 \pm 24,944$ & $5446 \pm 9,428$ & $5126 \pm 92,855$ & $4826 \pm 33,993$ \\
& F3 & $3563 \pm 41,096$ & $3313 \pm 57,348$ & $2740 \pm 16,329$ & $2513 \pm 9,428$ & $2280 \pm 43,204$ \\
Daya sebar (cm) & F1 & $4,6 \pm 0,216$ & $4,96 \pm 0,047$ & $5,2 \pm 0,081$ & $5,63 \pm 0,124$ & $6,2 \pm 0,141$ \\
F2 & $4,96 \pm 0,124$ & $5,36 \pm 0,094$ & $5,66 \pm 0,094$ & $6,03 \pm 0,047$ & $6,56 \pm 0,124$ \\
F3 & $5,56 \pm 0,124$ & $5,9 \pm 0,081$ & $6,16 \pm 0,047$ & $6,73 \pm 0,124$ & $7,1 \pm 0,141$ \\
\hline Keterangan : F1 = Krim Asam Laurat 10\% & & & \\
F2 = Krim Asam Laurat 20\% \\
F3 = Krim Asam Laurat 30\% \\
* Hasil yang diperoleh dalam bentuk nilai ratan $(\mathrm{n}=3) \pm$ standardeviasi
\end{tabular}

\section{PEMBAHASAN}

Penelitian ini menggunakan asam laurat sebagai zat aktif dari sediaan krim. Krim asam laurat yang dibuat dalam penelitian ini adalah F0 (0\% b/b), F1 (10\% b/b), F2 (20\% $\mathrm{b} / \mathrm{b})$, dan F3 (30\% b/b). Formula mengandung bahan aktif dan bahan tambahan yang sama tetapi jumlah asam laurat dan volume aquadest yang ditambahkan berbeda.

Hasil penelitian menunjukkan bahwa asam laurat dapat diformulasikan ke dalam bentuk sediaan krim dengan tipe minyak dalam air (m/a). Perbedaan konsentrasi asam laurat yang digunakan menyebabkan rasio fase air dan fase minyak pada penelitian ini bervariasi, pada krim asam laurat $10 \%$ (F1) rasio fase air dan minyak yakni $65: 35$, sedangkan untuk krim asam laurat 20\% (F2) 55 : 45, dan pada krim asam laurat 30\% (F3) 45 : 55. Menurut Anwar (2012) kondisi yang baik untuk fase terdispersi yakni antara 40$60 \%$. Pencampuran kedua fase menghasilkan sediaan krim yang lembut dan homogen secara visual.

Komponen penting dari krim asam laurat ini yakni emulgator yang terdiri dari poloxamer 407 (kolliphor 407) dan span 60, sebab zat aktif yang digunakan yakni asam laurat memiliki nilai HLB (HydrophilicLiphophilic Balance) yang hidrofilik, antara 16 hingga 17 , oleh sebab itu dipilih poloxamer 407 yang memiliki nilai HLB berkisar antara 18 hingga 23. Sedangkan span 60 merupakan emulgator yang bersifat lipofilik yang memiliki nilai HLB 4,7 dan dikombinasikan dengan kolliphor 407 agar menghasilkan sediaan krim yang stabil, kombinasi kedua emulgator tersebut untuk mendapatkan nilai HLB yang sesuai dengan nilai HLB butuh , karena sulit untuk mencari emulgator tunggal sesuai dengan HLB butuh, maka dari itu, untuk mencapai tujuan tersebut dikombinasi dua emulgator dengan nilai HLB rendah dan nilai HLB tinggi. Nilai HLB butuh untuk sediaan ini berkisar antara 15,1 hingga 15,39 sedangkan nilai HLB campuran kedua emulgator tersebut 15,34 . Pada sediaan krim ini juga ditambahkan Propilenglikol sebagai humektan untuk mencegah terjadinya penguapan air baik itu untuk sediaan maupun pada saat pemakaian dan untuk meningkatkan daya sebar sediaan.

Pengamatan organoleptis terhadap sediaan krim asam laurat selama 28 hari menunjukkan bahwa jumlah asam laurat mempengaruhi warna, bentuk, dan aroma sediaan yang dihasilkan. Keempat formula memiliki bentuk yang sama yakni krim dengan konsistensi baik dan tidak mengalami pemisahan antara basis krim dan asam laurat sebagai bahan aktif. Semakin banyak jumlah asam laurat yang ditambahkan maka intensitas warna krim semakin kekuningan dan baunya semakin aromatik. F3 merupakan formula krim dengan kandungan asam laurat terbesar sehingga berwarna putih kekuningan dan berbau sangat khas.

Selain uji organoleptis, sediaan krim asam laurat ini juga diuji homogenitas untuk mengetahui apakah terjadi pemisahan fase atau tidak dengan menggunakan kaca dimana diambil sejumlah krim dan dioleskan pada sekeping kaca kemudian ditutup dengan kaca lainnya. Dapat dilihat baik F0, F1, F2, F3, dan kontrol positif tidak terjadi pemisahan fase.

$\mathrm{pH}$ krim pada ketiga formula memenuhi nilai $\mathrm{pH}$ yang diharapkan dan relatif tidak berubah selama penyimpanan 28 hari, hal ini didukung oleh $\mathrm{pH}$ dari zat aktif sendiri yakni 4,0 dan $\mathrm{pH}$ bahan tambahan lainnya yang masih dalam batas $\mathrm{pH}$ kulit. 
Semakin tinggi konsentrasi asam laurat dalam krim maka semakin rendah $\mathrm{pH}$ dari sediaan krim. Profil $\mathrm{pH}$ sediaan dari ketiga formula krim dapat dilihat pada Grafik 1.



Grafik 1. Grafik hubungan antara pH dan lama penyimpanan terhadap sediaan krim

Berdasarkan analisis statistik dapat dilihat bahwa terdapat perbedaan bermakna pada masing-masing formula setiap minggu selama waktu simpan (28 hari). Perubahan $\mathrm{pH}$ sediaan selama penyimpanan menandakan kurang stabilnya sediaan selama penyimpanan. Ketidak stabilan ini dapat merusak produk selama penyimpanan atau penggunaan. Perubahan nilai $\mathrm{pH}$ dapat dipengaruh oleh komponen dalam formulasi yang terdegradasi oleh suhu tinggi saat pembuatan atau penyimpanan yang menghasilkan asam atau basa. Asam atau basa ini yang mempengaruhi $\mathrm{pH}$. Selain itu perubahan $\mathrm{pH}$ juga disebabkan faktor lingkungan seperti suhu, maupun penyimpanan yang kurang baik (Young et al., 2002).

Pemeriksaan viskositas sediaan menggunakan alat viskometer Brookfield, dapat dilihat bahwa semakin besar konsentrasi asam laurat dalam sediaan maka viskositas krim akan semakin menurun, dimana viskositas $F_{1}>F_{2}>$ F3. Hal ini disebabkan karena asam laurat membentuk ikatan hidrogen dengan air. Jadi semakin tinggi konsentrasi asam laurat dalam formula, maka asam laurat yang berlebih tidak dapat berikatan dengan air yang jumlahnya lebih sedikit, ikatan hidrogen antara asam laurat dan air semakin berkurang, sebab viskositas air naik seiring dengan adanya ikatan hidrogen (Bird, 1987). Oleh karena itu, viskositas sediaan akhir akan semakin menurun seperti yang diperlihatkan oleh F1,
F2, dan F3.Hasil pengujian viskositas krim dapat dilihat pada Grafik 2.



Grafik 2. Grafik hubungan antara viskositas

(kekentalan) danlama penyimpanan terhadap sediaan krim

Berdasarkan analisis statistik dapat dilihat bahwa pada uji viskositas terdapat perbedaan signifikan pada formula itu sendiri selama waktu penyimpanan (28 hari), perubahan viskositas sediaan dapat disebabkan karena peralatan yang digunakan untuk proses pengadukan yakni mortir dan stamper, dimana kecepatan pengadukan tidak dapat dikontrol seperti peralatan yang lebih modern yakni stirrer yang dapat dikontrol kecepatan pengadukannya (rpm), hal ini memengaruhi diameter globul yang terbentuk (Anwar, 2012). Sementara itu, pada proses pengadukan terjadi pembentukan busa sehingga seiring dengan peningkatan masa simpan maka busa tersebut akan terus berkurang, oleh karena itu batasan antara partikel satu dan lainnya menjadi renggang dan menyebabkan viskositas semakin menurun (Lachman et al, 2008). Terbentuknya busa tersebut dapat disebabkan surfaktan yang digunakan dalam formulasi memiliki nilai HLB yang tinggi (detergent) (Anwar, 2012).

Evaluasi stabilitas mutu fisik lainnya adalah daya sebar. Pengujian daya sebar sediaan menggunakan lempeng kaca berukuran $20 \mathrm{x}$ $20 \mathrm{~cm}$, mulai dari hari ke-0 sampai dengan hari ke-28 menunjukkan bahwa semakin lama sediaan disimpan maka semakin besar daya sebarnya. Pengujian daya sebar penting dilakukan untuk mengetahui sifat alir krim. Daya sebar berbanding terbalik dengan viskositas. Viskositas merupakan tahanan yang dimiliki oleh sediaan untuk bisa menyebar atau 
mengalir (Martin et al., 1993). Dimana semakin besar viskositas maka tahanan krim untuk bisa menyebar juga semakin besar dan daya sebarnya menjadi lebih kecil. Hal ini disebabkan karena semakin besar viskositas krim, semakin keras krim tersebut, sehingga semakin sukar menyebar. Pada krim yang mengandung asam laurat $30 \%$ (F3) memiliki daya sebar paling besar karena nilai viskositasnya paling kecil sehingga tahanan untuk dapat mengalir lebih kecil dibanding formula lain.Hasil pengujian daya sebar krimdapat dilihat pada Grafik 3.

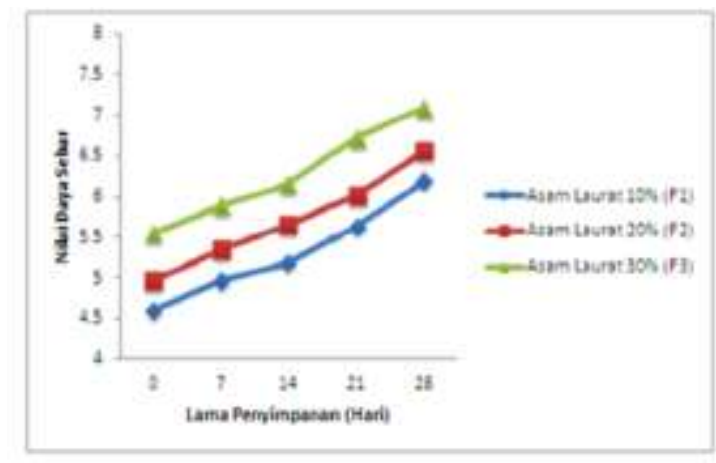

Grafik 3. Grafik hubungan antara daya sebar dan lama penyimpanan terhadap sediaan krim

Berdasarkan analisis statistik diperoleh hasil yang berbeda signifikan pada daya sebar formula itu sendiri selama waktu penyimpanan 28 hari. Perubahan daya sebar sediaan dapat dipengaruhi oleh perubahan viskositas sediaan. Dapat dilihat dari data, viskositas sediaan selama 28 hari penyimpanan mengalami penurunan, hal ini menyebabkan daya sebar sediaan semakin meningkat seiring dengan menurunnya viskositas sediaan.

Garg et al. (2002) menyatakan daya sebar yang menunjukkan konsistensi semisolida dalam memberikan kenyamanan pada saat penggunaaan adalah sebesar 5 - 7 $\mathrm{cm}$. Krim yang memiliki daya sebar pada rentang tersebut diperkirakan akan dengan mudah dioleskan dan disebarkan pada kulit. Beberapa formula yang diujikan memenuhi rentang daya sebar yang ditetapkan, yakni 5 $\mathrm{cm}$ hingga $7 \mathrm{~cm}$.

Berdasarkanhasil pengujian yang dilakukan pada sediaan krim asam laurat menunjukkan adanya aktivitas antibakteri dengan terbentuknya diameter daya hambat untuk konsentrasi 10\%, 20\%, dan 30\% terhadap Staphylococcus aureus berturut-turut sebesar 10,479 mm, 14,8 mm, dan 21,589mm, sedangkan untuk Pseudomonas aeruginosa berturut-turut $9,82 \mathrm{~mm}, 11,8 \mathrm{~mm}$, dan 14,256 mm. Pada kontrol positif untuk Staphylococcus aureus dengan menggunakan krim gentamisin mempunyai diameter daya hambat rata-rata sebesar $25,25 \mathrm{~mm}$, sedangkan kontrol positif untuk Pseudomonas aeruginosa mempunyai diameter daya hambat rata-rata sebesar 15,23 mm. Zona hambat krim asam laurat dapat dilihat pada gambar 1 dan 2 .
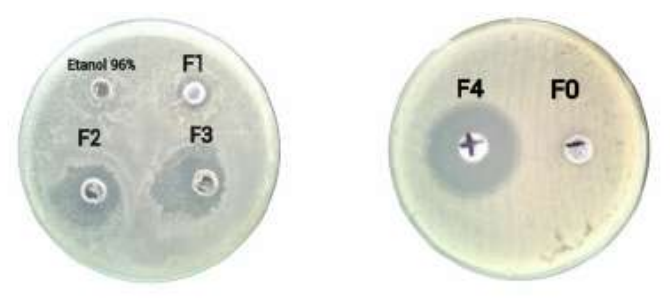

Gambar 1. Hasil aktivitas antibakteri krim asam laurat terhadap Staphylococcus aureus ATCC 25923
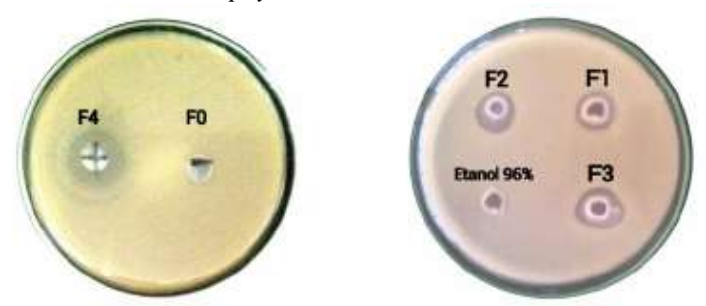

Gambar 2. Hasil aktivitas antibakteri krim asam laurat terhadap Pseudomonas aeruginosa ATCC 27853

Berdasarkan analisis statistik pada diameter zona hambat bakteri $S$. aureus untuk kontrol negatif dan ketiga formula didapatkan hasil yang berbeda nyata pada keempat sediaan, sama halnya untuk bakteri P.aeruginosa didapatkan hasil yang berbeda nyata pada keempat sediaan. Perbedaan tersebut bisa terjadi karena konsentrasi asam laurat pada masing-masing formula cukup berbeda jauh, dimana daya hambat terbesar ditemukan pada F3 yang mengandung asam laurat paling besar diantara formula lainnya. Proses pembuatan larutan uji dilakukan dengan menggunakan etanol 96\%, sebab asam laurat memiliki kelarutan yang tinggi terhadap etanol $96 \%$ (Rowe et al, 2009). Digunakan pelarut yang sesuai dengan asam laurat agar memudahkan proses difusi dari sediaan krim asam laurat. 
Dapat dilihat bahwa etanol $96 \%$ tidak membentuk daya hambat, hal ini mengindikasikan bahwa daya hambat yang terbentuk tidak dipengaruhi oleh pelarut melainkan karena aktivitas asam laurat yang terdapat dalam sediaan krim. Mekanisme kerja asam laurat sebagai antibakteri yakni dengan mempengaruhi membran sel bakteri sehingga sifat fluiditas membran berubah. Perubahan sifat fluiditas tersebut meningkatkan daya penetrasi asam laurat masuk ke dalam sel. Asam laurat dalam sel menghambat aktivitas enzim-enzim yang berperan dalam produksi energi dan transpor nutrien (Wang et al, 1993).

Dilihat dari efektivitasnya, sediaan krim ini cenderung lebih efektif pada S.aureus dibanding P.aeruginosa. Hal ini disebabkan karena kedua bakteri ini memiliki struktur dinding sel yang berbeda. Struktur membran sel bakteri Gram positif (S.aureus) berbeda dengan bakteri Gram negatif (P.aeruginosa). Pada bakteri Gram positif mengandung banyak lapisan peptidoglikan yang membentuk struktur yang tebal dan kaku, dan asam teikoat yang mengandung alkohol (gliserol atau ribitol). Ada 2 macam asam teikoat, yaitu asam lipoteikoat yang merentang di lapisan peptidoglikan dan terikat pada membran plasma, dan asam teikoat dinding yang terikat pada lapisan peptidoglikan. Dinding sel bakteri Gram negatif mengandung satu atau beberapa lapis peptidoglikan dan membran luar. Peptidoglikan terikat pada lipoprotein pada membran luar. Terdapat daerah periplasma, yaitu daerah yang terdapat diantara membran plasma dan membran luar. Periplasma berisi enzim degradasi konsentrasi tinggi serta protein-protein transpor. Dinding sel bakteri Gram negatif tidak mengandung asam teikoat, dan karena hanya mengandung sejumlah kecil peptidoglikan, maka dinding sel bakteri Gram negatif ini relatif lebih tahan terhadap kerusakan mekanis. Hal ini menyebabkan asam laurat lebih sulit untuk menembus dan merusak membran sel P.aeruginosa dibanding S.aureus (Pratiwi, 2008). Oleh sebab itu, daya hambat krim jauh lebih besar terhadap S.aureus dibanding P.aeruginosa.

\section{DAFTAR PUSTAKA}

Anonim. (1995). Farmakope Indonesia. Edisi IV. Jakarta: Departemen Kesehatan Republik Indonesia.

Anwar, E. (2012). Eksipien dalam Sediaan Farmasi : Karakterisasi dan Aplikasi. Jakarta: Dian Rakyat. 197, 229-230.

Bird, T. (1987). Kimia Fisik untuk Universitas. (Alih bahasa : Kwee le Tjien). Jakarta. Gramedia.

Garg, A., Aggarwal, D., Garg, S., \& Sigla, A.K. (2002). Spreading of Semisolid Formulation : An Update,

Pharmaceutical Technology. 84-102. [Serial Online]. www.pharmtech.com

Jawetz, E., J. L. Melnick., E. A. Adelberg., G. F. Brooks., J. S. Butel., L. N. Ornston. (2004). Mikrobiologi Kedokteran. Edisi ke-23(Alih bahasa: Huriawati.H., Chaerunnisa.R., Alifa .D., dan Aryana .D). Jakarta : EGC.

Kabara, J. J. (1984). Antimicrobial Agents Derived From Fatty Acids. Journal American Oil Chemists' Society. USA. 397-403

Lachman, L., Lieberman, H.A., \& Kanig, J.L. (2008). Teori dan Praktek Farmasi Industri. Edisi Ketiga.Jakarta : UI-Press. 1083-1085.

Martin, A., Swarbrick, J., \& Cammarata, A. (1993). Farmasi Fisik II. Jakarta : UI Press. 113- 117.

Mayasari, E. (2005). Pseudomonas aeruginosa ; Karakteristik, Infeksi dan Penanganan. Diakses pada tanggal 5 Januari, 2015, from http://library.usu.ac.id/

Pratiwi, T. S., (2008). Mikrobiologi Farmasi. Jakarta: Erlangga. 27-28, 188-190. 
Rowe, R. C., Paul, J. S., \& Marian, E. Q. (2009). Handbook Of Pharmaceutical. 384, 441-444, 506-508, 596-598, 697699.

Ryan, K. J., Champoux, J. J., Falkow, S., Plonde J.J., Drew, W.L., Neidhardt, F.C., \& Roy, C.G. (1994). Medical Microbiology An Introduction to Infectious Diseases. 3rd ed. Connecticut: Appleton\&Lange. 254.

Tangwatcharin, P. \& Khopaibool, P. (2012). Activity of Virgin Coconut Oil, Lauric Acid or Monolaurin in Combination with Lactic Acid Against Staphylococcus aureus. Southeast Asian Journal Trop Med Public Health. 43 (4), 974.

Tuminah, S. (2010). Efek Perbedaan Sumber dan Struktur Kimia Asam Lemak Jenuh terhadap Kesehatan. Buletin Penelitian Kesehatan. Vol.38 No.1. Pusat Penelitian dan Pengembangan Biomedis dan Farmasi. Jakarta. 46.

Wang, L., Yang, B., Parkin, K, L., Johnson, E, A., (1993). Inhibition of Listeria monocytogenes by Monoacylglycerols Synthesized from Coconut Oil and Milkfat by Lipase - Catalyzed Glycerolysis. Journal Agric Food Chem. 41

Warsa, U.C. (1994). Staphylococcus dalam Buku Ajar Mikrobiologi Kedokteran. Edisi Revisi. Jakarta : Penerbit Binarupa Aksara. 103-110.

Young, Anne. (2002). Practical Cosmetic Science. Mills and Boon Limited. London.39-4. 